Bangladesh J. Bot. 43(3): 345-352, 2014 (December)

\title{
STEM AND LEAF ANATOMY OF THREE TAXA IN LAMIACEAE
}

\author{
Melahat Ozcan* and Ozgur Eminagaoglu' ${ }^{1}$ \\ Department of Biology, Faculty of Science and Arts, \\ Artvin Coruh University, 08000 Artvin-Turkey
}

Key words: Stem and leaf, Anatomical characters

\begin{abstract}
Stem and leaf anatomy of Origanum rotundifolium Boiss., O. vulgare L. ssp. viride (Boiss.) Hayek, Teucrium hircanum L., belonging to Lamiaceae were characterized and compared. Some important differences were determined in the taxa. In addition, trichome diversity was investigated by light microscopy and three main types of trichomes (peltate, capitate glandular and non-glandular) were observed in three taxa.
\end{abstract}

\section{Introduction}

The Lamiaceae is a large family which is represented by about 258 genera and 3500 species in the world (Duarte and Lopes 2007). It is the third largest family in Turkey with 45 genera and 574 species of which 256 are endemic (Güner et al. 2000) and the country is regarded as a gene center for this family (Başer 1993).

Origanum L. genus is represented by 25 taxa in the Turkish flora (Güner et al. 2000). Almost a half of them (12) are endemic to Turkey. Some species contain phenolic substances such as carvacrol and thymol. Thymol is also used as a starter in the synthesis of some pharmacological active ingredients, for tooth filling, in the preparation of antiseptic baths and soaps and in the preservation of some foods (Baytop 1999). Teucrium L. is a large and polymorphic genus of the Lamiaceae. The genus Teucrium comprises totally 44 taxa belonging to 8 sections in Turkish flora (Yildirimli 2008). Trichomes are among the most useful taxonomic characters in Teucrium L. (Navarro and El Oualidi 2000) described infrageneric relationships between sections depending on trichome types.

Many species of Lamiaceae have been used as herbal teas in Turkey and most of them have great importance due to their economic values and many of them are used as raw material in cosmetic industry. Some species are used in official and traditional medicines in Anatolia, Europe and China (Baytop 1999, Cui et al. 2003). Some species are cultivated as ornemantal plants (Rudy 2004). The morphology and anatomy of several species have been studied so far (Tahir et al. 1995). In Lamiaceae, the systematic value of trichome types was demonstrated by Abu-Assab and Cantino (1987) in the subtribe Melittidinae (Dumort.) Endlicher. Glandular trichomes producing essential oils of commercial value are widespread on leaves and fowers of the Lamiaceae and their structures have been examined anatomically and micromorphologically by several authors (Akçin et al. 2011, Kaya et al. 2007). In recent years, anatomical characters have been used in taxonomy (Agbagwa and Ndukwu 2004, Kharazian 2007, Eminagaoglu et al. 2012, Ozcan et al. 2014).

The main object of this study is to investigate detailed description of anatomical structures of the stem and leaf in three Lamiaceae taxa by using light microscopy. The variation in leaf characters is discussed with respect to their potential systematic value and in relation to our previous work.

*Author for correspondance: <melahat.ozcan@artvin.edu.tr>. ${ }^{1}$ Department of Forest Engineering, Faculty of Forestry, Artvin Coruh University, 08000 Artvin-Turkey. 


\section{Materials and Methods}

Plant samples were collected from Artvin Province and dried according to herbarium technigues and stored in Artvin Coruh University Herbarium (ARTH). The localities and collection data are listed in below.

Origanum rotundifolium Boiss.; A8 Artvin: Yeni mahalle (İskebe), stony slope, $500 \mathrm{~m}$, 08.vii.2011, Ö. Emin. 8836.

O. vulgare L. ssp. viride (Boiss.) Hayek; A8 Artvin: Hatila Valley National Park, roadside, 570 m, 08.vii.2011, Ö. Emin. 8839.

Teucrium hircanum L.; A8 Artvin: Hatila Valley National Park, roadside, 600 m, 08.vii.2011, Ö. Emin. 8838 .

Anatomical investigations were carried out on the cross-sections of the upper and lower stems, the leaves and surface sections of the leaves. All sections were prepared manually and stained with Hematoxyline solution. They are preserved on the permanent slides in glyceringelatin solution. The photographs of the sections were taken using an Olympus BX-53 research microscobe with digital camera attachment DP-73.

Five cross-sections from at least three different individual plants of each taxon were measured for each sample to assess the consistency of anatomical characters. Ten peripheral slides were prepared for each taxon and 50 stomatal lengths were measured on each slide. The stomatal index was calculated.

\section{Results and Discussion}

In this study, three taxa belonging to Lamiaceae were investigated and their anatomical characters are represented here for the first time from Turkey. Two of the investigated taxa belong to the genus Origanum and one species belongs to the Teucrium. Cross sections in the middle parts of stems and transverse section of the lamina, midrib and both epidermises of leaf were investigated, and representative anatomical characters are summarized in Tables 1 and 2.

Table 1. Stem features of three Lamiaceae taxa.

\begin{tabular}{lllc}
\hline Characters & O. rotundifolium & O. vulgare ssp. viride & T. hircanum \\
\hline Epidermis length $(\mu \mathrm{m})$ & $14.47 \pm 0.59$ & $13.53 \pm 0.84$ & $14.53 \pm 0.34$ \\
Epidermis width $(\mu \mathrm{m})$ & $25.73 \pm 1.12$ & $19.00 \pm 0.57$ & $20.87 \pm 1.48$ \\
Cortex thickness in the corner $(\mu \mathrm{m})$ & $201.93 \pm 19.84$ & $143.40 \pm 4.85$ & $203.40 \pm 5.14$ \\
Number of cortex layer & $12-13$ & $11-14$ & $12-15$ \\
Corner collenchyma thickness $(\mu \mathrm{m})$ & $112.73 \pm 10.88$ & $71.60 \pm 7.67$ & $125.00 \pm 4.37$ \\
Vascular bundle & & & \\
$\quad$ & $56.53 \pm 4.99$ & $58.87 \pm 1.37$ & $67.90 \pm 1.21$ \\
$\quad$ Phloem length $(\mu \mathrm{m})$ & $294.13 \pm 7.72$ & $352.80 \pm 15.84$ & $339.20 \pm 10.29$ \\
$\quad$ Xylem length $(\mu \mathrm{m})$ & $30.31 \pm 0.96$ & $23.05 \pm 0.81$ & $28.83 \pm 0.93$ \\
Trachea size $(\mu \mathrm{m})$ & $79.20 \pm 3.59$ & $66.73 \pm 2.36$ & $85.65 \pm 2.11$ \\
Pith cell size $(\mu \mathrm{m})$ & & & \\
\hline
\end{tabular}

The stem anatomical characters on the three taxa of this family showed similar anatomical characteristics, but some important distinctions are also found among the taxa. The stem structure in all the investigated species is more or less uniform. In cross-section, the stem is quadrangular, collenchyma tissue covers a large area at the corner and one-two layers between the corners. These features are previously reported in some other investigated members by several authors 
(Metcalfe and Chalk 1972, Bosabalitis and Kokkini 1997, Gönüz and Özörgücü 1999, Dinç et al. 2008). On the other hand, the cortex size and collenchyma thickenes in the corners, trachea size and pith cell size $O$. vulgare ssp. viride has the smallest values among the three taxa. The vascular cambium is visible in two Origanum taxa, but not the other. Two investigated Origanum taxa have pith cavity at the center of the stems. In previous study Gönüz and Özörgücü (1999) reported starch in O. onites L., but two Origanum taxa investigated in the present study do not have starch.

Table 2. Leaf anatomical characteristics of three Lamiaceae taxa.

\begin{tabular}{|c|c|c|c|c|c|}
\hline \multicolumn{3}{|c|}{ Characters } & O. rotundifolium & O. vulgare ssp. viride & T. hircanum \\
\hline \multirow{2}{*}{\multicolumn{2}{|c|}{ Upper epidermis }} & length $(\mu \mathrm{m})$ & $20.97 \pm 0.93$ & $22.07 \pm 0.82$ & $17.30 \pm 1.84$ \\
\hline & & width $(\mu \mathrm{m})$ & $32.17 \pm 2.53$ & $32.07 \pm 2.58$ & $26.00 \pm 3.47$ \\
\hline \multirow{2}{*}{\multicolumn{2}{|c|}{ Lower epidermis }} & length $(\mu \mathrm{m})$ & $19.93 \pm 1.06$ & $14.88 \pm 0.69$ & $9.30 \pm 0.44$ \\
\hline & & width $(\mu \mathrm{m})$ & $30.63 \pm 2.13$ & $21.40 \pm 1.13$ & $13.40 \pm 0.97$ \\
\hline \multicolumn{3}{|c|}{ Midrib mesophyll breadth $(\mu \mathrm{m})$} & $447.20 \pm 35.41$ & $378.40 \pm 10.68$ & $538.40 \pm 27.30$ \\
\hline \multicolumn{3}{|c|}{ Lamina mesophyll breadth $(\mu \mathrm{m})$} & $208.93 \pm 7.92$ & $134.27 \pm 3.94$ & $86.90 \pm 3.47$ \\
\hline \multicolumn{3}{|c|}{ Trachea size $(\mu \mathrm{m})$} & $14.90 \pm 0.66$ & $12.17 \pm 0.36$ & $16.35 \pm 0.76$ \\
\hline \multirow{2}{*}{\multicolumn{2}{|c|}{ Vascular bundle }} & length $(\mu \mathrm{m})$ & $168.80 \pm 11.18$ & $140.80 \pm 4.07$ & $219.03 \pm 41.41$ \\
\hline & & breadth $(\mu \mathrm{m})$ & $260.20 \pm 6.30$ & $360.00 \pm 35.54$ & $442.07 \pm 10.43$ \\
\hline \multirow{4}{*}{\multicolumn{3}{|c|}{$\begin{array}{l}\text { Number of the palisade cell line } \\
\text { Number of the spongy cell line } \\
\text { Adaxial cuticle thickness }(\mu \mathrm{m}) \\
\text { surface epidermal cell }\end{array}$}} & $1-2$ & 1 & 2 \\
\hline & & & $4-7$ & $4-5$ & $1-2$ \\
\hline & & & $4.10 \pm 0.24$ & $4.10 \pm 0.10$ & $2.80 \pm 0.20$ \\
\hline & & & $\begin{array}{l}\text { Polygonal shape, } \\
\text { sinuous wall }\end{array}$ & $\begin{array}{l}\text { Polygonal shape, } \\
\text { straight wall }\end{array}$ & $\begin{array}{l}\text { Irregular shape, } \\
\text { sinuous wall }\end{array}$ \\
\hline \multirow{2}{*}{\multicolumn{3}{|c|}{$\begin{array}{r}\text { Stomata length }(\mu \mathrm{m}) \\
\text { width }(\mu \mathrm{m})\end{array}$}} & $22.64 \pm 0.99$ & $23.45 \pm 0.68$ & 0 \\
\hline & & & $16.36 \pm 0.66$ & $17.17 \pm 0.39$ & 0 \\
\hline \multicolumn{3}{|c|}{ Stomatal index } & $11.52 \pm 0.98$ & $5.99 \pm 0.57$ & 0 \\
\hline \multirow{7}{*}{$\begin{array}{l}\text { Abaxial } \\
\text { surface }\end{array}$} & \multirow{2}{*}{\multicolumn{2}{|c|}{$\begin{array}{l}\text { Number of stomata }\left(1 \mathrm{~mm}^{2}\right) \\
\text { cuticle thickness }(\mu \mathrm{m})\end{array}$}} & $56.25 \pm 5.92$ & $65 \pm 6.11$ & 0 \\
\hline & & & $3.50 \pm 0.22$ & $3.80 \pm 0.20$ & $2.40 \pm 0.24$ \\
\hline & \multicolumn{2}{|c|}{ epidermal cell } & $\begin{array}{l}\text { Irregular shape, } \\
\text { sinuous wall }\end{array}$ & $\begin{array}{l}\text { Irregular shape, } \\
\text { repand wall }\end{array}$ & $\begin{array}{l}\text { Irregular shape, } \\
\text { sinuous wall }\end{array}$ \\
\hline & \multicolumn{2}{|c|}{ Stomata length $(\mu \mathrm{m})$} & $23.08 \pm 0.41$ & $22.81 \pm 0.26$ & $20.62 \pm 0.07$ \\
\hline & & vidth $(\mu \mathrm{m})$ & $16.58 \pm 0.64$ & $17.17 \pm 0.39$ & $16.92 \pm 0.12$ \\
\hline & \multicolumn{2}{|c|}{ Stomatal index } & $15.76 \pm 0.71$ & $21.62 \pm 0.62$ & $18.27 \pm 1.10$ \\
\hline & \multicolumn{2}{|c|}{ Number of stomata $\left(1 \mathrm{~mm}^{2}\right)$} & $121 \pm 5.79$ & $335 \pm 14.97$ & $430 \pm 29.95$ \\
\hline
\end{tabular}

\pm : Standard error.

Origanum vulgare has four subspecies in Turkey and $O$. vulgare ssp. viride is one of them. Petiole anatomical features of $O$. vulgare ssp. vulgare were examined by Akçin et al. (2011) and multi-lobed and broadly arc shaped vascular bundle, eglandular and glandular hairs were reported. In addition, leaf anatomy of $O$. vulgare ssp. viridulum (Martrin-Donos) Nyman was previously investigated from Greece by Bosabalitis and Kokkini (1997). This taxon is a synonym of $O$. vulgare ssp. viride. Bosabalitis and Kokkini (1997) investigated three subspecies of Origanum vulgare from Greece and reported that the leaves of $O$. vulgare subsp. viridulum have the thinnest lamina (totally 57.53 \pm 04.46 ) among the four subspecies. Moreover, it was reported that the cells of the palisade parenchyma were not elongate as in the typical dicot leaf and they were short, leaving large intercellular spaces between them.

Our results are generally in accordance to these previous reports. In Turkey, however, the palisade cells of $C$. vulgare ssp. viride are elongate and almost a half of the leaf lamina. Furthermore, Bosabalitis and Kokkini (1997) reported that the upper leaf surface possesses more 
peltate glandular trichomes than the lower one. Lamina mesophyll thickenes of this taxon is found to be $134.27 \pm 03.94 \mu \mathrm{m}$. According to this result, the plant growing in Turkey has much thicker leaf lamina than that of Greece. Additionaly, stomatal frequency per $\mathrm{mm}^{2}$ in both surfaces in Turkey is many more than that of Greece (Table 2). The vascular bundle is arc shaped and twolobed in the leaf midrib.

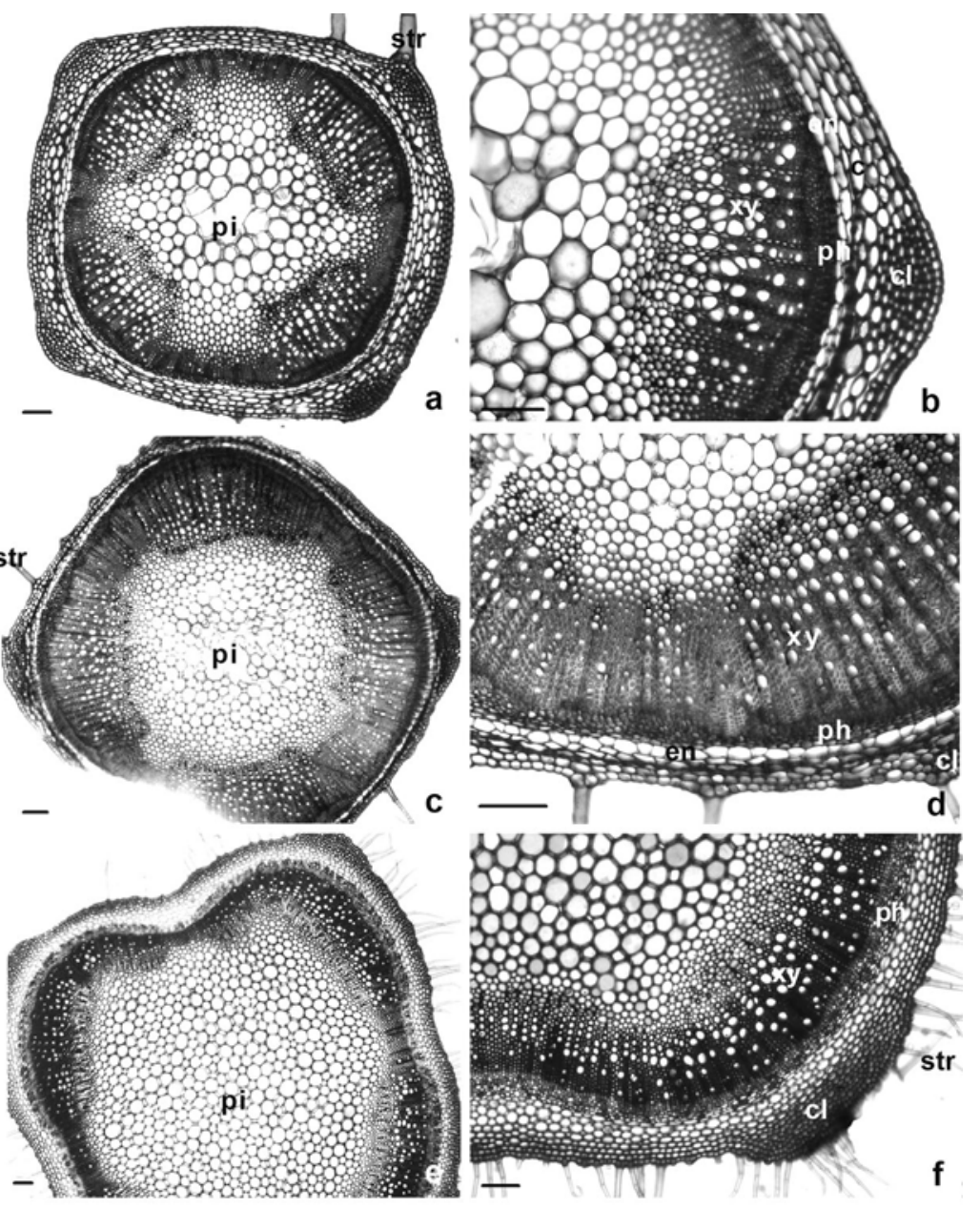

Fig. 1. Cross section of stem. a, b: Origanum rotundifolium, c, d: O. vulgare ssp. viride, e, f: Teucrium hircanum. cl: collenchyma, en: endodermis, ph: phloem, pi: pith, str: simple trichome, xy: xylem. Bar $=100 \mu \mathrm{m}$.

Trichome types and morphology of the indumentum have taxonomic values in Lamiaceae (Metcalfe and Chalk 1972, Cantino 1990, Navarro and El Oualidi 2000). Three different trichome types on the stems of the investigated taxa were observed: peltate, capitate glandular and nonglandular trichomes. Capitate glandular and peltate trichomes can be distinguished by head size and stalk length (Ascensão and Pais 1998). Non-glandular trichomes are sparce in $O$. rotundifolium, while it is densely found in Teucrium hircanum (Figs 4, 6). Two examined Origanum taxa have peltat glandular trichomes, sunken inside the epidermal layers, while these 
are one stalk cell in T. hircanum. Mráz (1998) mentioned that glandular trichomes have also a taxonomic value at the specific and a subspecific level in Teucrium. In addition to simple nonglandular trichomes, flagelliform hairs are observed in T. hircanum (Fig. 5). These type trichomes were previously reported in T. montanum by Dinç et al. (2011).

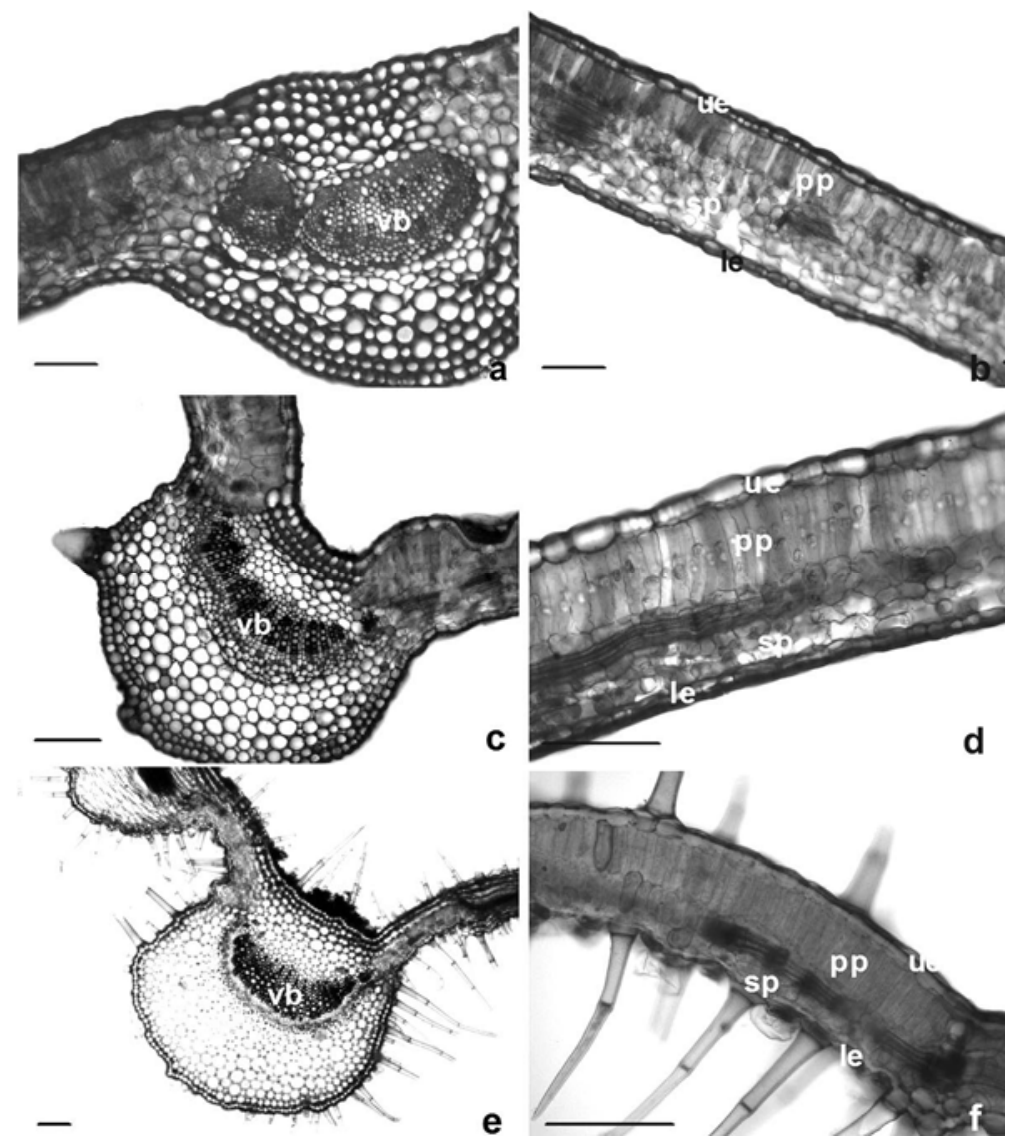

Fig. 2. Cross section of leaf. a, b: Origanum rotundifolium, c, d: O. vulgare ssp. viride, e, f: Teucrium hircanum. le: lower epidermis, pp: palisade parenchyma, sp: spongy parenchyma, ue: upper epidermis, vb: vascular bundle. $\mathrm{Bar}=100 \mu \mathrm{m}$.

The leaves of the three taxa show dorsiventral mesophyll. However number of palisade layer and spongy layer differ among the taxa. The palisade tissue covers almost a half of the mesophyll in O. vulgare ssp. viride, while it comprises much of the mesophyll (about $70-80 \%$ ) of $T$. hircanum (Fig. 2f). It is reported that high density of trichomes and thick palisade tissue of mesophyll could be interpreted as xerophytic characters. These features were reported in $T$. sandrasicum (Dinç et al. 2008), T. montanum and T. polium (Dinç et al. 2011). The upper epidermal cells are distinctly larger than the lower ones in T. hircanum, while it is almost equal to the lower one in O. rotundifolium. The spherocrystals were reported in T. sandrasicum by Dinç et al. (2008), but they are not found in T. hircanum or other two taxa. T. hircanum has hypostomatic leaf and densely trichomes occurring the epidermis. These characters are also interpreted as xeromorphic type and previously reported in T. sandrasicum by Dinç et al. (2008). 


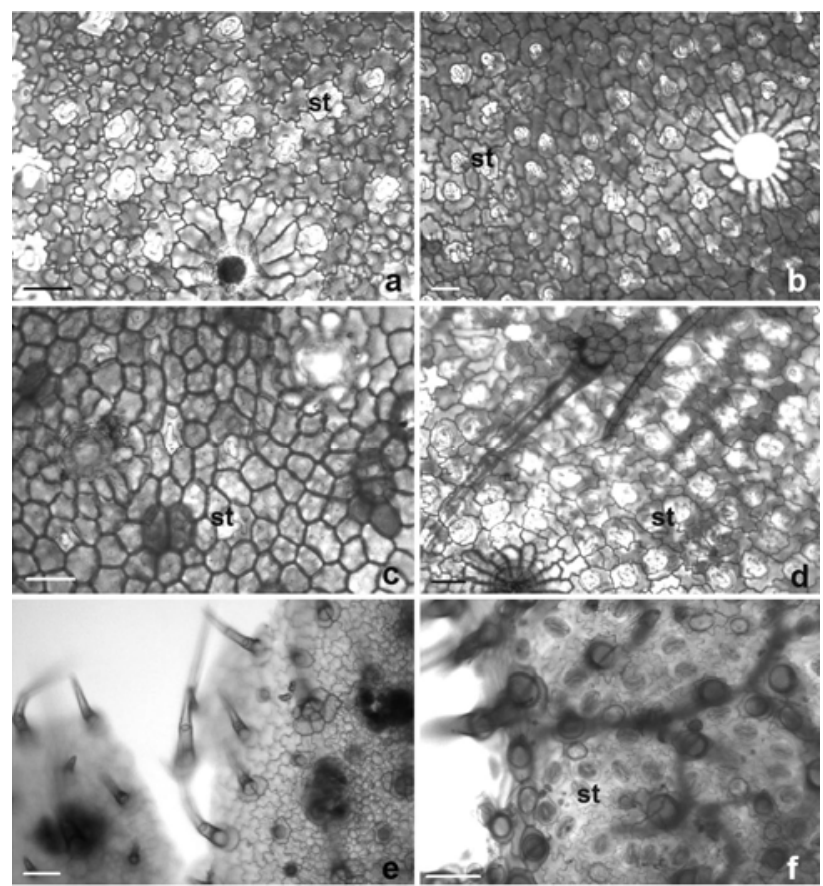

Fig. 3. Peripheral section of leaf. a, b: Origanum rotundifolium, c, d: O. vulgare ssp. viride, e, f: Teucrium hircanum. a, c, e: adaxial surface, b, d, f: abaxial surface. st: stomata. Bar $=50 \mu \mathrm{m}$.
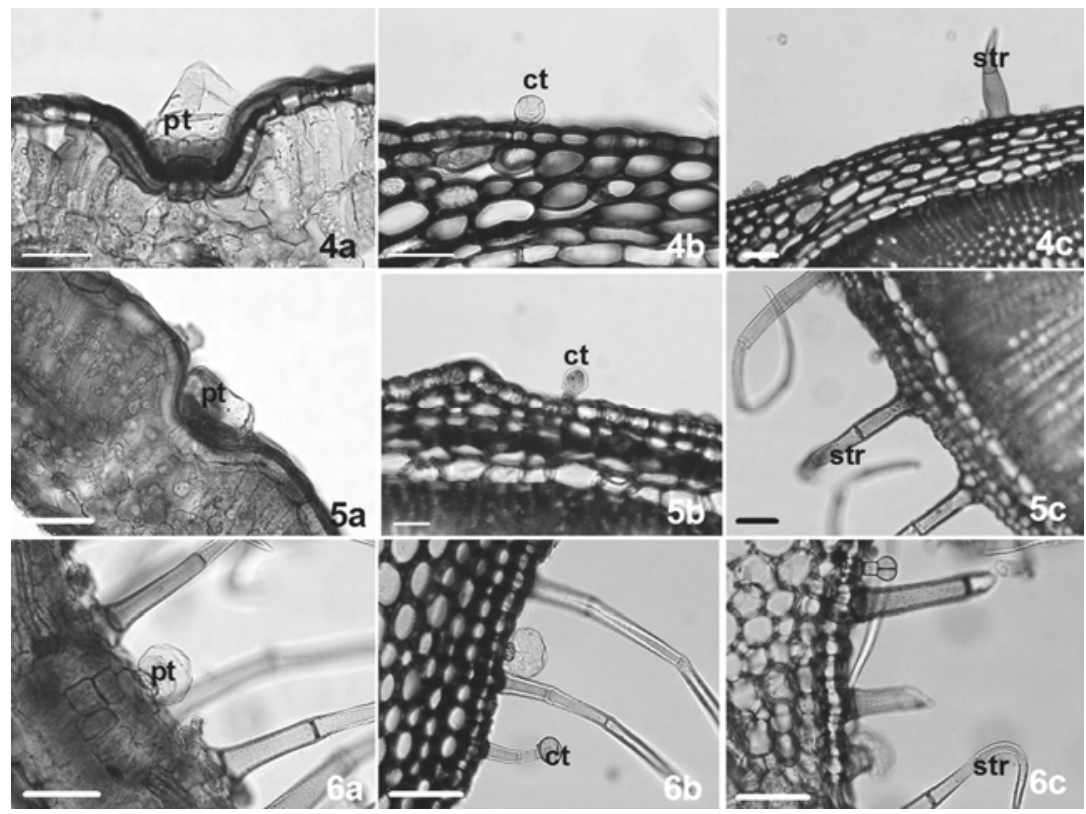

Fig. 4-6. Trichome types. 4: Origanum rotundifolium, 5: O. vulgare ssp. viride, 6: Teucrium hircanum. a: peltat trichome, b: capitat trichome, c: simple trichome. pt: peltat trichome, ct: capitat trichome, str: simple trichome. Bar $=50 \mu \mathrm{m}$. 
In peripheral sections, it is observed that the two Origanum taxa have amphistomatic leaf, while T. hircanum has one. Inamdar and Bhatt (1972), who studied 33 species in 17 genera of the Lamiaceae, found that in the majority of species, stomata occurred exclusively on the lower leaf surface. However, Cantino (1990) mentioned that both hypostomatic and amphistomatic leaves are found in the members of the family, the presence of the latter type of leaves being slightly more frequent. Stomata are diacytic or rarely anomocytic type in the two Origanum taxa, whereas it is anomocytic type in T. hircanum. Stomata densely occur in abaxial surfaces of all the taxa. According to the dimension, $T$. hircanum has many more stomata occurred only abaxial surface. On the other hand, between Origanum taxa, the number of stomata in O. vulgare ssp. viride is three times as many as that of $O$. rotundifolium. Stomatal lengths are almost equal in all taxa.

\section{References}

Abu-Assab MS and Cantino PD 1987. Phyllogenetic implications of leaf anatomy in subtribe Mellittidinñ (Labiatae) and related taxa. J. Arnold Arboretum 68: 1-34.

Agbagwa OI and Ndukwu BC 2004. The value of morphoanatomical features in the systematic of Cucurbita L. (Cucurbitaceae) species in Nigeria. Afr. J. Biotechnol. 3(10): 541-546.

Akçin OE, Özyurt MS and Şenel G 2011. Petiole anatomy of some Lamiaceae taxa. Pak. J. Bot. 43(3): 14371443.

Ascensão L and Pais MS 1998. The leaf capitate trichomes of Leonotis leonurus: histochemistry, ultrastructure and secretion. Ann. Bot-London 81: 263-271.

Başer KHC 1993. Essential oils of Anatolian Lamiaceae: A profile. Acta Hortic. 333: 217-238.

Baytop T 1999. Türkiye'de Bitkilerle Tedavi (Geçmişte ve Bugün). 2. Baskı, Nobel Tıp Kitapevleri, Çapaİstanbul, Konak-İzmir, Sihhiye-Ankara. pp. 142-144.

Bosabalitis AM and Kokkini S 1997. Infraspecific variation of leaf anatomy in Origanum vulgare grown wild in Greece. Bot. J. Linn. Soc. 123: 353-362.

Cantino PD 1990. The phylogenetic significance of stomata and trichomes in the Labiatae and Verbenaceae. J. Arnold Arboretum 71: 323-370.

Cui SY, Chen XG and $\mathrm{Hu} \mathrm{Z} \mathrm{2003.} \mathrm{Identification} \mathrm{and} \mathrm{determination} \mathrm{of} \mathrm{ecdysone} \mathrm{and} \mathrm{phenylpropanoid}$ glucoside and flavonoids in Lamium maculatum by carpillary zone electrophoresis. Biomed. Chromatogr. 17: 477-482.

Dinç M, Duran A, Pinar M and Öztürk M 2008. Anatomy, palynology and nutlet micromorphology of Turkish endemic Teucrium sandrasicum (Lamiaceae). Biologia 63(5): 637-641.

Dinç M, Doğu S, Doğru Koca A and Kaya B 2011. Anatomical and nutlet differentiation between Teucrium montanum and T. polium from Turkey. Biologia 66(3): 448-453.

Duarte MDR and Lopes JF 2007. Stem and leaf anatomy of Plectranthus neochilus Schltr., Lamiaceae. Rev. Bras. Farmacogn. 17(4): 549-556.

Eminagaoglu Ö, Özcan M and Kültür S 2012. Contributions to the leaf and stem anatomy of Tradescantia fluminensis Vell. (Commelinaceae): An alien species new to the flora of Turkey. ACU. J. For .Fac. 13(2): 270-277.

Gönüz A and Özörgücü B 1999. An investigation on the morphology, anatomy and ecology of Origanum onites L. Turk. J. Bot. 23: 19-32.

Güner A, Özhatay N, Ekim T and Başer KHC (eds.) 2000. Flora of Turkey and the east Aegean islands, 11. Edinburg University Press, Edinburg.

Inamdar JA and Bhatt DC 1972. Structure and development of stomata in some Labiatae. Ann. Bot-London 36: 335-344.

Kaya A, Demirci B and Başer KHC 2007. Micromorphology of glandular trichomes of Nepeta congesta Fisch. \& Mey. var. congesta (Lamiaceae) and chemical analysis of the essential oils. S. Afr. J. Bot. 73(1) 29-34. 
Kharazian N 2007. The taxonomy and variation of leaf anatomical characters in the genus Aegilops L. (Poaceae) in Iran. Turk. J. Bot. 31:1-9.

Metcalfe R and Chalk L 1972. Anatomy of the Dicotyledons. Vol. 2, Clarendon Press, Oxford. pp. 10411053.

Mráz P 1998. The structure and development of the glandular trichomes of Teucrium montanum (Lamiaceae). Biol. Bratislava 53(1): 65-72.

Navarro T and El Qualidi L 2000. Trichome morphology in Teucrium L. (Labiatae). A taxonomic review. Anales Jard. Bot. Madrid 57(2): 277-297.

Ozcan M, Unver MC, Eminagaoglu O 2014. Comparative anatomical and ecological investigations on some Centaurea S. L. (Asteraceae) taxa from (Turkey) and their taxonomic significance. Pak. J. Bot. 46(4): 1287-1301.

Rudy MR 2004. Plant evaluation notes, a comparative study of ground cover Lamium. Chicago Bot. Garden 23: 1-4.

Tahir SS, Khenam M and Husain SZ 1995. A micromorphological study of Pogostemon Desf. species (Lamiaceae) from Bangladesh. Pak. J. Bot. 27(1): 73-82.

Yildirimli S 2008. The chorology of the Turkish species of Lamiaceae family. Ot Sistematik Botanik Dergisi 14: 151-198.

(Manuscript received on 22 July, 2013; revised on 20 August, 2014) 